\title{
Pola trauma tembus toraks di Instalasi Rawat Darurat Bedah RSUP Prof. Dr. R. D. Kandou Manado periode Juli 2013 - Juni 2015
}

\author{
${ }^{1}$ Christianto Kissra \\ ${ }^{2}$ Adrian Tangkilisan \\ ${ }^{2}$ Heber B. Sapan
}

\author{
${ }^{1}$ Kandidat Skripsi Fakultas Kedokteran Universitas Sam Ratulangi Manado \\ ${ }^{2}$ Bagian Bedah Fakultas Kedokteran Universitas Sam Ratulangi Manado \\ Email: Christiantokissra12161@gmail.com
}

\begin{abstract}
Trauma continues to be major public health problem worldwide since it is associated with high morbidity and mortality in developed and developing countries. Penetrating thoracic trauma respresents a common and challenging problem whether it is caused either by gunshot or by non-gunshot-related accidents (stabs, traffic accidents). This study was aimed to obtain the profile of penetrating thoracic trauma in Surgery Emergency Unit of Prof. Dr. R. D. Kandou Hospital Manado from July 2013 to June 2015. This was a retrospactive descriptive study using the medical record data of penetrating thoracic trauma patients. The results showed that there were 31 patients of penetrating thoracic trauma out of 108 patients of thoracic trauma patients. Most cases occurred in $2014(48.41 \%)$. Based on age group, the majority of patients were at the age group 16-30 years old (58.05\%). Based on sex, most patients were males (96.80\%). The most common causes of penetrating thoracic trauma was puncture wounds/stabs $(80.64 \%)$ and the most common intrathoracic complication was hemothorax (58.1\%).
\end{abstract}

Keywords: trauma, penetrating thoracic trauma.

\begin{abstract}
Abstrak: Trauma merupakan masalah kesehatan masyarakat yang utama di seluruh dunia karena dikaitkan dengan morbiditas dan mortalitas yang tinggi baik di negara maju dan berkembang. Trauma tembus toraks merupakan masalah umum dan menantang, baik oleh tembakan atau nontembakan-kecelakanaan (tikaman, kecelakaan lalu lintas). Penelitian ini bertujuan untuk mendapatkan pola trauma tembus toraks di IRDB RSUP Prof. Dr. R. D. Kandou Manado periode Juli 2013 - Juni 2015. Jenis penelitian ialah deskriptif retrospektif dengan menggunakan data rekam medik pasien trauma tembus toraks di IRDB RSU Prof. Dr. R. D. Kandou Manado. Hasil penelitian mendapatkan jumlah kasus trauma tembus toraks sebanyak 31 pasien dari 108 pasien trauma toraks. Kasus terbanyak terjadi pada tahun $2014(48,41 \%)$. Berdasarkan kelompok usia mayoritas penderita trauma tembus toraks $(58,05 \%)$ pada usia 16-30 tahun. Berdasarkan jenis kelamin sebagian besar penderita $(96,80 \%)$ berjenis kelamin laki-laki. Penyebab trauma tembus toraks terbanyak karena luka tusukan/tikaman $(80,64 \%)$, dan komplikasi intratoraks terbanyak yaitu hemotoraks $(58,1 \%)$.
\end{abstract}

Kata kunci: trauma, trauma tembus toraks

Sejak lama trauma merupakan suatu masalah medis yang terabaikan (neglected disease) oleh para dokter, masyarakat, maupun pemerintah di seluruh dunia. Pada kenyataannya, trauma ialah kejadian yang bersifat holistik dan menyebabkan hilangnya produktivitas seseorang. Dewasa ini trauma melanda dunia bagaikan wabah karena dalam kehidupan modern penggunaan kendaraan automotif dan senjata api semakin luas. ${ }^{1}$ Trauma terus menjadi masalah kesehatan masyarakat yang utama di seluruh dunia karena dikaitkan dengan morbiditas dan mortalitas yang tinggi baik di negara maju dan berkembang. Trauma juga dilaporkan 
menjadi penyebab utama kematian, perawatan di rumah sakit, dan kecacatan jangka panjang dalam empat dekade pertama kehidupan. ${ }^{2}$

Trauma toraks terjadi hampir $50 \%$ dari seluruh kasus kecelakaan. ${ }^{3}$ Trauma yang terkait dengan trauma toraks mencapai 30$40 \%$ dari yang diterima rumah sakit dan $20-25 \%$ dari trauma dikaitkan dengan kematian. Trauma tembus toraks mencapai 1-13\% dari jumlah total trauma ini. Pada laporan studi yang dipublikasikan, $85 \%$ dari trauma ini dapat dikelola, baik dengan observasi atau drainase pleura, sementara hanya $15-30 \%$ kasus yang memerlukan intervensi bedah untuk trauma pada organ yang mungkin berakibat fatal. ${ }^{4}$

Pada umumnya trauma tajam atau tembus toraks berurusan dengan pihak kepolisian atau hukum, Oleh karena itu membuat laporan dalam status penyakit harus baik dan lengkap untuk mencegah hal-hal yang tidak diinginkan di kemudian hari. Bila harus dikerjakan operasi, laporan juga harus dibuat dengan baik dan lengkap. ${ }^{5}$ Trauma tembus toraks merupakan masalah umum dan menantang, yang disebabkan baik oleh tembakan atau nontembakan-kecelakaan (tikaman, kecelakaan lalu lintas). ${ }^{6}$

Di wilayah Los Angeles dan Medical Center University of Southern California, yang merupakan pusat trauma terbesar di wilayah tersebut dengan sekitar 7000 trauma yang diterima per tahun, trauma tembus toraks di laporkan sekitar $7 \%$ dari seluruh trauma yang diterima atau sekitar $16 \%$ dari trauma tembus yang diterima. ${ }^{7}$

Penelitian ini bertujuan untuk mendapatkan pola trauma tembus toraks di IRDB RSUP Prof. Dr. R. D. Kandou Manado periode Juli 2014- Juni 2015.

\section{METODE PENELITIAN}

Jenis penelitian ini ialah deskriptif retrospektif pada pasien trauma tembus toraks di IRDB RSU Prof. Dr. R. D. Kandou Manado. Subjek penelitian ialah semua data rekam medik pasien trauma tembus toraks di IRDB RSUP Prof. Dr. R. D. Kandou Manado periode Juli 2013-Juni
2015. Variabel penelitian yang diteliti yaitu: tahun, usia, jenis kelamin, dan penyebab trauma tembus toraks

\section{HASIL PENELITIAN}

Berdasarkan hasil penelitian yang telah dilakukan dengan menggunakan data rekam medik pasien trauma tembus toraks di IRDB RSU Prof. Dr. R. D. Kandou Manado periode Juli 2013 sampai Juni 2015 diperoleh sebanyak 31 pasien trauma tembus toraks dari total 108 pasien trauma toraks.

Dari total 31 pasien trauma tembus toraks di IRDB RSUP Prof. Dr. R. D. Kandou Manado periode Juli 2013 sampai Juni 2015 didapatkan pada tahun 2013 sebanyak 5 orang $(16,10 \%)$, tahun 2014 sebanyak 15 orang $(48,14 \%)$, dan tahun 2015 sebanyak 11 orang $(35,49 \%)$.

Tabel 1. Distribusi trauma tembus toraks berdasarkan tahun

\begin{tabular}{ccc}
\hline Tahun & $\begin{array}{c}\text { Kasus trauma } \\
\text { tembus toraks }\end{array}$ & $\begin{array}{c}\text { Total kasus } \\
\text { trauma toraks }\end{array}$ \\
\hline 2013 & $5(16,10 \%)$ & $16(14,81 \%)$ \\
2014 & $15(48,41 \%)$ & $65(60,19 \%)$ \\
2015 & $11(35,49 \%)$ & $27(25 \%)$ \\
Total & $31(100 \%)$ & $108(100 \%)$ \\
\hline
\end{tabular}

Berdasarkan kelompok usia dari total 31 pasien, didapatkan yang terbanyak ialah antara 16-30 tahun sebanyak 18 orang $(58.05 \%)$ (Tabel 2).

Tabel 2. Distribusi trauma tembus toraks berdasarkan kelompok usia

\begin{tabular}{ccc}
\hline $\begin{array}{c}\text { Kelompok } \\
\text { usia }\end{array}$ & $\begin{array}{c}\text { Jumlah kasus } \\
\text { (orang) }\end{array}$ & $\mathbf{( \% )}$ \\
\hline $0-15$ tahun & 2 & 6,44 \\
16-30 tahun & 18 & 58,05 \\
$31-45$ tahun & 9 & 29,01 \\
46-60 tahun & 1 & 3,25 \\
$>60$ tahun & 1 & 3,25 \\
Total & 31 & 100 \\
\hline
\end{tabular}

Dari total 31 pasien, pada laki-laki didapatkan sebanyak 30 orang $(96,80 \%)$ dan pada perempuan didapatkan sebanyak 1 orang $(3,20 \%)$ (Tabel 3). 
Tabel 3. Distribusi trauma tembus toraks berdasarkan jenis kelamin

\begin{tabular}{cccc}
\hline Tahun & \multicolumn{3}{c}{ Jumlah kasus (\%) } \\
\cline { 2 - 4 } 2013 & $5(100 \%)$ & $0(0 \%)$ & $5(16,13 \%)$ \\
2014 & $15(93,15)$ & $1(6.85 \%)$ & $16(51,63 \%)$ \\
2015 & $10(100 \%)$ & $0(0 \%)$ & $10(32,24 \%)$ \\
Total & $30(96,80 \%)$ & $1(3.20 \%)$ & $31(100 \%)$ \\
\hline
\end{tabular}

Dari total 31 orang pasien trauma tembus toraks didapatkan penyebab trauma karena tusukan/tikaman yang terbanyak yaitu 25 orang $(80,64 \%)$ (Tabel 4). Komplikasi intratoraks yang terbanyak ialah hemotoraks $(58,1 \%)$.

Tabel 4. Distribusi trauma tembus toraks berdasarkan faktor penyebab

\begin{tabular}{ccc}
\hline $\begin{array}{c}\text { Faktor } \\
\text { penyebab }\end{array}$ & $\begin{array}{c}\text { Jumlah } \\
\text { kasus } \\
\text { (orang) }\end{array}$ & $\mathbf{( \% )}$ \\
\hline Tusukan/tikaman & 25 & 80,64 \\
Tembakan/panah & 5 & 16,12 \\
KLL & 1 & 3,24 \\
Total & 31 & 100 \\
\hline
\end{tabular}

\section{BAHASAN}

Dari data pasien hasil penelitian mengenai pola trauma tembus toraks di IRDB RSU Prof. Dr. R. D. kandou Manado periode Juli 2013 sampai Juni 2015 didapatkan pasien trauma tembus toraks sebanyak 31 orang pasien dari 108 orang pasien trauma toraks, dengan distribusi trauma tembus toraks berdasarkan tahun didapatkan pada tahun 2013 sebanyak 5 orang $(16,10 \%)$, tahun 2014 sebanyak 15 orang $(48,41 \%)$, dan tahun 2015 sebanyak $(35,49 \%)$. Data ini menunjukkan bahwa kasus trauma tembus terbanyak terjadi pada tahun 2014 diikuti tahun 2015 dan tahun 2013 (Tabel 1).

Distribusi trauma tembus berdasarkan usia didapatkan kelompok usia terbanyak ialah 16-30 tahun sebanyak 18 orang $(58,05 \%)$ dan kedua terbanyak ialah $31-45$ tahun sebanyak 9 orang $(29,01 \%)$ (Tabel 2). Hal ini ditunjang sesuai data kepustakaan yang menyatakan bahwa trauma merupakan penyebab kematian utama pada kelompok usia di bawah 35 tahun. Di Indonesia, trauma merupakan penyebab kematian nomor 4, tetapi pada kelompok usia 15-25 tahun, merupakan penyebab kematian utama. ${ }^{1}$

Distribusi trauma tembus toraks berdasarkan jenis kelamin dari total 31 orang pasien didapatkan laki-laki sebanyak 30 orang $(96,80 \%)$ dan perempuan sebanyak 1 orang $(3,20 \%)$. Seringkali saat di bawah pengaruh alkohol laki-laki tidak dapat mengontrol prilaku sehingga terjadi tindakan kriminal menggunakan senjata tajam yang dapat menyebabkan trauma tembus toraks. Berdasarkan Riskesdas 2013, menurut jenis kelamin, maka prevalensi peminum alkohol lebih besar pada laki-laki dibandingkan perempuan. ${ }^{8}$

Distribusi trauma tembus toraks berdasarkan faktor penyebab dari total 31 orang pasien trauma tembus toraks didapatkan penyebab trauma karena tusukan/tikaman sebanyak 25 orang (80,64\%), tembakan/panah sebanyak 5 orang $(16,12 \%)$, dan KLL sebanyak 1 orang $(3,24 \%)$. Faktor penyebab trauma tembus terbanyak karena tusukan/tikaman mungkin karena semakin meningkatnya angka kriminalitas yang menggunakan senjata tajam dibawah pengaruh alkohol. Berdasarkan Riskesdas 2013, secara nasional prevalensi penduduk usia 10 tahun ke atas yang minum alkohol selama 12 bulan terakhir sebesar 3,0\%. Sulawesi Utara termasuk provinsi dengan prevalensi peminum alkohol termasuk tinggi yaitu sebesar $17,4 \%{ }^{8}$

\section{SIMPULAN}

Dari hasil penelitian terhadap 108 pasien trauma tembus toraks di IRDB RSUP Prof. Dr. R. D. Kandou Manado periode Juli 2013 sampai Juni 2015 dapat disimpulkan bahwa trauma tembus toraks terbanyak terjadi pada tahun 2014 dan yang paling sedikit terjadi pada tahun 2013. Mayoritas pasien trauma tembus toraks ialah jenis kelamin laki-laki, usia 16-30 tahun, dengan penyebab luka tusukan/ tikaman. 
DAFTAR PUSTAKA

1. Sjamsuhidajat R, de Jong $\mathbf{W}$, editors. Buku Ajar Ilmu Bedah (3rd ed). Jakarta: EGC, 2010; p. 121-2, 502-6.

2. Al-koudmani I, Darwish B, Al-kateb K, Taifour Y. Chest trauma experience over eleven year period at Al-Mouassat University Teaching HospitalDamascus: a retrospective review of 888 cases. J Cardiothorac Surg. 2012;7:35.

3. Prasenohadi, Sunartomo T. Penatalaksanaan pasien trauma dengan fraktur iga multiple. Majalah Kedokteran Terapi Intensif. 2012;2:166.

4. Paci M, Ferrari G, Annesi V, de Franco S, Guasti G, Sgarbi G: The role of diagnoctic VATS in penetrating thoracic injuries. World J Emerg Surg.
2006;1:30.

5. Rachmat KB. Trauma toraks. Kumpulan Kuliah Ilmu Bedah. Tanggerang: Binarupa Aksara; 198-202, 204-8.

6. Bertolaccini L, Rizzardi G, Filice MJ, Spada E, Terzi A. The "ending neglect" of roentgenograms in penetrating chest trauma. J Thorac Dis. 2010;2:197-8.

7. Demetriades D, Velmahos GC. Penetrating injuries of the chest: indications for operation. Scandinav J Surg.

8. umum dan perilaku penduduk. 2002;91:41-5.

9. Profil kesehatan Indonesia 2013. Gambaran Departemen Kesehatan Republik Indonesia. 2013; p. 23. Available from: http: //www.depkes.go.id/ downloads/publikasi/profil\%20kesehat an\%20Indonesia\%202013.pdf 